811.163.41'367.62

$81 ' 1: 165$

https://doi.org/10.18485/kij.2020.67.1.7

\author{
АЛЕКСАНДРА С. ЈОВАНОВИЋ \\ Институт за српски језик САНУ \\ Београд
}

Оригинални научни рад

Примљен: 18.05.2020.

Прихваћен: 04.06.2020.

\title{
О ЛЕКСЕМИ КАО ИЗ УГЛА ТЕОРИЈЕ ПРОТОТИПА**
}

\begin{abstract}
У овом раду, ослањајући се на постулате когнитивне лингвистике - и то пре свега на теорију прототипа, разматрамо значењску мрежу лексеме као. Анализа је корпусно заснована, а њен ток је следећи. Најпре издвајамо и ближе осветљавамо прототипичну употребу ове лексеме - ону у поредбеној конструкцији. Затим пратимо два основна смера значењског гранања речи као: прагматикализацију и граматикализацију. Прагматикализација подразумева континуум од употребе ове лексеме у поредбеној конструкцији до употребе у својству катафоричког средства и испуњивача. Граматикализација се пак односи на њен пут од већ постојеће граматичке јединице ка јединици која је у још већем степену граматичка - што се огледа у употребама у семикопулативним конструкцијама и конструкцијама у функцији актуелног квалификатива. Најзад, покушавамо да понудимо алтернативан одговор на питање у коју врсту речи лексема као спада, при чему врсте речи сагледавамо као категорије са расплинутим границама.
\end{abstract}

Кључне речи: српски језик, лексема као, поредбена конструкција, прагматикализација, граматикализација, врсте речи, теорија прототипа, когнитивна лингвистика.

\section{I. Увод}

1. Предмет и циљ. Још давне 1958. г. М. Московљевић поставља следеће питање (које је и наслов његовог рада): у коју категорију спада реч као? Исто питање поставићемо поново, а на њега ћемо покушати да одговоримо из угла теорије прототипа (в. Тејлор ${ }^{3} 2003$, 2019; Лејкоф 2014; за примену ове теорије на изучавање српског језика в. Кликовац $22006,2017,2018)$. Наш задатак биће да, анализирајући значењску мрежу лексеме као, размотримо степен припадности ове лексеме категорији везника, прилога и речци, имајући у виду свако од њених

*aleksandra.jovanovic@isj.sanu.ac.rs

** Ово истраживање резултат је рада на предмету Теорија прототипа у проучавању српског језика (докторске студије), под менторством проф. др Душке Кликовац. 
значења понаособ. Везничким спојевима као што и као да нећемо се бавити у овом раду.

2. МАтЕРИЈАЛ. Корпус за истраживање представљајУ примери ексцерпирани из електронског Корпуса савременог српског језика (ЕК) (укупно 800), те примери из речничког чланка о лексеми као из РСАНУ. ${ }^{1}$ Као помоћни корпус (око 100 примера), за разговорну сферу употребе ове лексеме, послужили су примери из Савић/Половина 1989 и Милосављевић 2014, примери које смо ексцерпирали из електронских извора доступних преко Google претраживача (ГП), те примери које смо сами забележили.

3. ДоСАДАШњА ЛИтЕРАТУРА. СТатус лексеме Као у граматичкој и лексикографској литератури веома је шаренолик. С. Новаковић ( $\left.{ }^{2} 1902: 20\right)$ ову реч одређује као прилог за начин или меру (претпостављамо да аутор има у виду случајеве када ова реч „одређује” глагол), Т. Маретић (1963: 543) сврстава је у начинске или поредбене везнике (разматрајући примере са поредбеним конструкцијама), а М. Стевановић $\left({ }^{5} 1986: 382\right)$ говори о везнику као $u$, који означава поређење. Љуб. Поповић (112008: 256, 277) лексему као третира у поредбеним конструкцијама као везник, а ван њих, нпр. када је посреди конституентска функција актуелног квалификатива - као речцу. У РСАНУ лексема као забележена је у функцији поредбено-начинског и исказног везника, прилога и речце, а у РМС и РСЈ у функцији везника и прилога.

О синтаксичким, семантичким и прагматичким особеностима лексеме као доста је писано и ван граматичке и лексикографске литературе. Истраживачка пажња углавном је усмерена на поредбене конструкције са овом речју (исп. нпр. Варју 2008; Миљковић 2016), док се осталим типовима посвећује знатно мање простора. Прагматичке употребе лексеме као сагледаване су из угла теорије релевантности у радовима М. Мишковић Луковић (2003, 2010).

\section{II. Значењска мрежа лексеме као}

На основу анализе корпуса дошли смо до следећег. Основно и прототипично значење лексеме као јесте поредбено (т. 1). Прототипичним значењем сматрамо оно које је централно у том смислу што су са њим умрежена сва остала значења (исп. Тејлор 2019: 130). ${ }^{2}$ Значењско умрежавање лексеме као тече у

${ }^{1}$ Нису разматрана она значења лексеме као која су архаична или дијалекатска, попут узрочног (нпр. А ни ияарев зет не познаје више мехур сахибије, ко давно је то било, а једном га је видио у животу (РСАНУ)).

${ }^{2}$ Тејлор (2019: 130-134) говори о централности, истакнутости и фреквентности као релевантним критеријумима за одређивање прототипичног значење лексеме. У зависности од приступа, централност се може тумачити различито. Централно значење је оно које је историјски најстарије, из којег су се метафором, метонимијом и др. механизмима развила сва остала (ово значење ћемо ми третирати као основно). Из развојне перспективе, централно значење је оно које дете прво усвоји, а из лексикографске - оно које семантичару омогућава да најпроницљивије опише полисемску структуру једне лексеме, тј. оно из којег 'зраче' сва остала значења. Други критеријум се односи на когнитивну истакнутост прототипичног значења у односу на сва остала; ово се може 


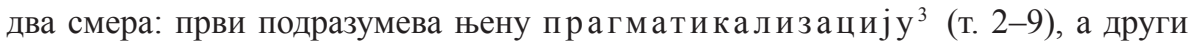
граматикализацију ${ }^{4}$ (т. 10).

1. ПореъЕњЕ. Ослањајући се на Баудлија и Гентнера (2005: 196), поређење ћемо дефинисати као 'динамички' процес који се састоји из две етапе: (1) поравнања (alignment) структуре појмова (мете - појма који се пореди, и базе - појма са којим се мета пореди $)$ и (2) пројекције (projection) истакнутих дистинктивних карактеристика базе на мету. Поменуте две фазе важе и када је посреди дословно поређење (типа Зебра је као коњ), и када је реч о метафоричкој интерпретацији (idem: 197). Будући да Баудли и Гентнер у цитираном раду покушавају да утврде како се метафоре разумевају, застанимо на тренутак код метафоричке интерпретације. Врло упрошћено преносимо неке од њихових кључних тврдњи. Метафоре су својеврсне аналогије, које подразумевају два изнад поменута процеса: поравнање и пројекцију. Начин поравнања структуре појмова мења се зависно од тога да ли је реч о конвенционализованој или неконвенционализованој (тзв. novel) метафори. Другим речима, ако база нема конвенционализовано метафоричко значење, онда је посреди поређење (одн. хоризонтално поравнање структуре мете и базе); када пак база досегне ниво конвенционализације, дата метафора се може интерпретирати или као поређење или као категоризација (у другом случају долази до вертикалног по равнања - мета је члан наткатегорије именоване базом) (idem: 199). Ово, у ствари, значи да је свака појмовна метафора у првој фази поређење (исп. idem: 198). Баудли и Гентнер (2005: 200) указују и на значај граматичког формулисања: поредбена конструкција (нпр. Ум је као компјутер) зазива поређење мете са базом, а копулативна (нпр. $У_{\mathcal{M}}$ је компјутер) категоризацију мете као члана категорије именоване базом. И код поређења и код категоризације укључени су процеси поравнања и пројекције; разлика лежи, како истичу аутори, у степену пројекције: поређење подразумева високо селективну пројекцију (само истакнуте карактеристике се пројектују са базе на мету), док категоризацију карактерише потпуна пројекција (idem: 199). ${ }^{6}$

експериментално проверити, нпр. тестом лексичке одлуке. Фреквентност као критеријум може бити само индикатор прототипичности, али мора бити испуњен најмање још један од два већ наведена критеријума.

${ }^{3}$ Прагматикализација представља процес развоја дискурсних маркера и модалних речци нпр. од глагола (рецимо, мислим, пази, изгледа и сл.) (в. Норд 2009: 21-23).

${ }^{4}$ Граматикализација је процес при ком неке језичке јединице (нпр. лексичке, прагматичке) постају граматичке одн. при ком неке граматичке јединице постају то у још већој мери (Вишер 2006: 129).

${ }^{5}$ Баудли и Гентнер (2005) користе термине target / base concept.

${ }^{6}$ Исп. следеће Лејкофово запажање. Исказ Естер Вилијамс је риба неистинит је јер се њиме тврди да је Естер Вилијамс риба - а она то није; исказ Естер Вилијамс је права риба истинит је јер се у њему не каже да је Естер Вилијамс риба, него да добро плива, тј. да се одлично сналази у води (а притом се не тврди да има шкрге, крљушт, пераја итд.) (Лејкоф 2014: 136). Са сличним значењем може се употребити и као-конструкција: Естер Вилијамс је као риба (= одлично се сналази у води). 
1.1. Мотивисани оваквим виђењем поређења, у прву групу издвојили смо примере типа (1-2) - где се структура мете и базе 'поравнава', искрсавају подударања, а онда се са базе на мету пројектује дато специфично својство базе које мету осветљава на нов начин. Тако у примеру (1) поравнањем структуре појмова влАст и плод искрсавају подударања, а онда се истакнута карактеристика плодА да 'тек када узри, опадне' пројектује на влАст. У наставку реченице је својство базе које се пројектује на мету и експлицирано.

(1) Власт је као плод; док не буде зрео неће пасти ма колико тресли дрва на којима расте. (ЕК)

(2) Ја имам свој завичај и ја сам срећан, а човек без завичаја је као биљка без корена. (ЕК)

У овај тип поређења спадале би и таутологије Власт к(а)о власт, Мајка $\kappa(a)$ о мајка и сл. У њима фаза поравнања изостаје (како су мета и база исти појам), а истакнута карактеристика се, условно речено, пројектује са базе на мету (нпр. за појам мАЈкА истакнуто својство је 'брижност').

1.2. За разлику од претходне, у овој групи је увек експлицирано својство по којем се подударају структуре мете и базе (у пр. 3 то је 'приврженост'), а оно што се пројектује (као истакнуто својство) са базе на мету јесте степен/количина (у пр. 3 степен 'привржености'). На синтаксичком плану ово се огледа у томе што је центар поредбене синтагме придевска јединица којом је именовано дато својство 'подударања', а поредбена одредба има прилошку вредност, тј. на прилошки начин спецификује придевску јединицу (исп. употребу корелатива онолико/толико/тако одн. заменљивост лексеме као прилогом колико у наведеним примерима).

(3) Дабетић, који је био Адунићев курир у рату и [онолико] привржен му као [што је привржено] пашче, удари Кречка песницом. (ЕК) $\approx$ Дабетић, који је био Адунићев курир у рату и [онолико] привржен му колико [је привржено] пашче, удари Кречка песницом.

(4) „,ТТко] лепа је као [што је леп] анђео” - шапну ми Сарајлија. (ЕК)

Занимљиво је да се у примерима (3-4) поредбена одредба исказана именичком јединицом може развити у реченицу. Да бисмо увидели зашто је то тако, размотрићемо конструисане примере (3a-б), својеврсне парафразе примера (3). Они показују да се поредбена одредба може развити у реченицу само ако је експлицирано својство подударања структуре мете и базе одн. ако је експлициран резултат поравнања њихових структура. Ово поравнање је и иконички назначено: особина по којој се структуре базе и мете подударају артикулисана је и слева и здесна (в. пр. 3б).

(3а) *Дабетић је као [што је] пашче.

(3б) Дабетић је понизан као [што је понизно] пашче.

1.3. Примери што следе творе континуум са претходнима. Разлика је једино у томе што се поредбеном одредбом спецификује (и то углавном начински) гла- 
голска ситуација - исп. у пр. (5) онако/брзо, а у пр. (6) сурово и нагло (дато као додатна информација).

(5) Пахуље над димњаком постају сузе. Куће тону у снег који расте [онако/брзо] као [што расте] тесто. (ЕК)

(6) И шта ће бити? Оно што Адунић каже: „Издаће те, сурово и нагло, као [што издаје] жена. Притом ће наћи начина да те унизи, упрља и осрамоти као нико." (ЕК)

1.4. Веома слични наведенима јесу примери у којима својство у ком се подударају структуре мете и базе има прилошку вредност, а пројектовањем истакнутог дистинктивног својства базе на мету спецификује се дато прилошко значење (у пр. 7 - како нежно? онако нежно као што се смеши дете).

(7) Смешила се [онако] нежно као [што се нежно смеши] дете, и својим дугим прстима показивала на свој пас, одакле је свитала зора новога нараштаја. (ЕK)

1.5. Сасвим специфични случајеви јесу они у којима су мета и база различите временске равни (апстрактни појмови) - у пр. (8) мета је 'садашњи тренутак', а база 'малочас'; у пр. (9) налазимо дистинкцију никад : сад. Фаза поравнања подразумева проналажење подударности између структура ових временских равни одн. (метонимијски) између читавих ситуација. Те подударности могу бити и експлициране - в. пр. (8). Као у примерима из т. 1.2-1.4, поредбена одредба се може развити у реченицу. Овоме типу можемо прикључити и невелик број примера у којима је реч о различитим просторним равнима (нпр. овде : тамо, в. пр. 10).

(8) Соба је понова била уска и мрачна, као [што је била уска и мрачна] малочас. (ЕК)

(9) Никад као [што разазнава] сад он не разазнаваше да су једино осећања сачувала своју бескрајну вредност. (ЕК)

(10) Тамо или овде, или овде или тамо, са које год стране да погледаш, како год то да назовеш, тамо није као [што је] овде и овде није као [што је] тамо. (ГП)

2. Апроксимативност. Својеврсни прелаз ка развитку апроксимативног значења представљали би примери где још увек имамо поређење мете са базом, али је мета неодређена; прецизније, она се не може именовати јер не постоји одговарајућа лексема, те је исказана неодређеном именичком заменицом нешто (пр. 11-12). Тако у примеру (11) 'главно јело' није типично 'роловано месо' - али може се, донекле, упоредити са њиме као прототипичним представником надређене категорије. Значење приближности прототипичном члану врло је лепо уочљиво у примерима где се поред неодређених заменица користе и други маркери несигурности, нпр. конструкције са (нетипичним) копулативним глаголом доћи, који уноси значење 'рачунања' и 'процењивања' (исп. Јовановић 
2018), или где се база додатно модификује како би поређење мете са њом било „прикладније” (пр. 12). ${ }^{7}$ Према Михачу (2009: 71), у конструкцијама овог типа развија се значење апроксимативне сличности (approximative similarity), јер и даље, синтаксички, имамо поредбену конструкцију.

(11) Ја сам се баш најела тог предјела. А за главно јело, нешто као [што је] роловано месо, али са неким посебним сосом, не само печурке, ја не знам шта је оно, али укусно, јако. (Милосављевић 2014: 180)

(12) Не само да је битно ваше залагање на часовима већ је битно и залагање у ваншколским активностима, тзв. „clubs”. То му дође нешто као [што су] школске секције код нас, само што Американци много више придају на значају него ми. (ГП)

У примерима (13-14) више немамо поредбену конструкцију (мета + као + база), већ као долази непосредно испред предиката (што је типично прилошка позиција) и има апроксимативну вредност: њиме се наглашава приближност, схваћена као ублажавање (Мишковић 2003: 173) - нпр. у (13) субјекатски појам 'игра', али не у типичном смислу, односно, изостају поједине компоненте које прате типичну ситуацију 'играња', што је десним контекстом и назначено. Слично налазимо и у примерима (14-15). У пр. (15) реч као се односи на предикат, иако стоји иза њега.

(13) И понашала се као кловн. Нешто се церекала. Па, час код младе, па час код младожење. Па, као игра. А кад игра, нема оно да се опусти, па да се весели, да ужива него оно, очи јој к’о на уљу, на свестране гледа. (Милосављевић 2014: 180)

(14) Једино доцније што би је покаткад као узнемирило, то је био он сам, њен муж, Томча. (ЕК)

(15) А: Ова спава, а онај напољу чисти као снег. А Аца оде тамо у кућу. / Б: Па је л’ чисти стварно? / А: Па да, помало лопатом око капије. Не може пуно јер је тежак снег. А и није му нешто добро. (разг., Viber)

3. ФингиРАна ФАКтивност. На Примере (13-15) надовезују се примери типа (16-19), у којима се сада јавља већина типичних пропратних компоненти одређене ситуације, док оно што је језгро изостаје. Тако, у примеру (16) субјекатски појам 'шепа', правећи се да га боле ноге. ${ }^{8}$ Људ. Поповић (2012: 386) истиче да маркери овог типа имају епистемичку функцију - рангирају информацију у погледу процене степена њене истинитости. У том смислу, као упућује на фингирану фактивност садржаја који је под његовим опсегом. Осим уз глагол, реч као у овом значењу може стајати и уз друге врсте речи, нпр. уз прилоге

${ }^{7}$ Ако би се уз реч као употребио маркер баш, изостала би семантика приближности. То је зато што баш уноси значење прецизности (исп. Мишковић Луковић 2010: 75), које искључује могућност да поредбено као развије апроксимативно значење.

${ }^{8}$ Ово може подсетити на случај лажног пиштоља: лажни пиштољ има сва својства правог пиштоља сем функционалних - из њега се не може пуцати (исп. ЛејкофЏонсон 1980: 120-121; Тејлор ${ }^{3} 2003:$ 96-97). 
(пр. 17). Под његовим опсегом може бити и читава клауза, када је интонационо издвојено (пр. 18), а често се јавља и у изразу као бајаги (пр. 19).

(16) А: Иначе, она ће ти сад, дођеш код ње, чим те види, она почне да шепа. Као боле је ноге. Међутим, (повишена интонација) чим замакне она (смех)... / А, Б и В: (смех и углас) Не зна на којој нози шепа. (Милосављевић 2014: 152)

(17) Потплатили смо једну циганску породицу да, као случајно, застане на утрини изнад куле, да разапне чергу. (ЕК)

(18) Идем често на Камени мост, стојим ослоњен на ограду. Као, гледам у зеленкасту, хитру Бистрицу, а вребам испод ока. (Д. Николић, Краљица забаве, Београд: Нолит, 1996, 181)

(19) Држава, која је као бајаги дигла руке од директних интервенција у сетвене планове и откуп, доноси уредбу о забрани извоза жита, подиже царину на увоз. (ЕК)

4. Хипотетичност. Свој епистемички потенцијал лексема као шири следећом употребом: ситуација ${ }^{9}$ која је под њеним опсегом задобија хипотетичну вредност - нпр. субјекатски појам о њој сања, машта и сл. По правилу, глагол са таквим значењем постоји или у реченици (пр. 20) или у непосредном контексту (пр. 21). И овде је реч о рангирању степена истинитости информације, с тим што као не упућује на фингирану фактивност (као у т. 3), већ на хипотетичност ситуације која је под његовим опсегом. Субјекатски појам (типично кореферентан са говорником) сели се из тренутка говорења у неки други (хипотетични) тренутак, и говори из тог тренутка:

(20) МАЈКА ПИНТОРОВИЋА: Како си спавала? / ХАСАНАГИНИЦА: ... Сањала, као дојим онај ђурђевак, сав мирише на моје млеко. Цео дан ме боле груди. (ЕК)

(21) Лоше спавам - прокуратор се осмехну - и све време видим у сну месечев зрак. Тако је смешно, замислите. Као - ја шетам по томе зраку... (EK)

5. УВОЂЕЊЕ УПРАВНОГ И НЕУПРАВНОГ ГОВОРА. На УПОТребе аПрОКСИМаТИВНОГ и епистемичког као наслања се употреба при цитирању: тада је као лексички показатељ туђег говора и типично се распоређује иза глагола говорења. Овом речју се може увести и дослован и недослован управни говор. Када се уводи недослован управни говор, активира се апроксимативно значење - 'приближно оригиналномдословном говору': у пр. (22) тетка је викнула нешто слично цитираним речима. Увођење дословног говора речју као знатно је ређе, тј. дословни говор чешће ће се увести деиктичном речју овако (в. пр. 23).

(22) Укључио телевизор, апарат, неки дан, кад је тетка викнула као „Оћу мало мир. Тишине!” (Савић/Половина 1989: 144).

${ }^{9}$ В. Илић (1977: 353-354) сматра да лексема као овде детерминише глагол одн. радњу. 
(23) Каже она мени овако: „Девојчице, предговори су на књижевним критикама.” (Милосављевић 2014: 161)

Увођењем неуправног говора помоћу речи као имплицира се да је извор информације неодређен, самим тим и непознат, па говорник има потребу за дистанцирањем од фактивности садржаја који уводи (исп. Поповић Људ. 2012: 384):

(24) Чула сам као да Јерков на испиту увек даје Андрића и Црњанског. (разг.)

Лексема као може се јавити и самостално у цитатној функцији, без претходно експлицираног глагола говорења, тј. уместо глагола говорења (пр. 26-27). Сличну функцију има и енглеска лексема like, тј. конструкција be + like (исп. Ромеин/Ланг 1991, пр. 28), а - под утицајем енглеског - блиску употребу налазимо и у француском и шпанском језику (Михач 2009: 85, за шпански в. пр. 29). Оваквим увођењем туђег говора замагљује се граница између управног и неуправног говора.

(26) Умрли смо од смеха! Она се сва збунила. Као „Шта се смејете?”, па се увредила. (Савић/Половина 1989: 161-162).

(27) Регент јој је нешто одбрусио, као: зашто га већ једном не остави на миру, зар не види да је не жели. (ЕК)

(28) Shane's like: "She's in Baltimore” (Ромеин/Ланг 1991: 241)

(29) A: Has visto tu rivalidad entre los negros y los latinos? / B: Si, como 'oh, no hables con ellos'. (Михач 2009: 85)

6. ЕвалуАцијА. Употреба лексеме као при цитирању (за увођење неуправног говора), у којој се имплицира дистанцираност и резервисаност говорника од туђих речи које преноси (пр. 24), твори континуум са евалуативним као - које имплицира негативан став говорника према пропозицији коју изриче. Негативан став се најчешће препознаје као иронија или сарказам. М. Мишковић (2003: 180) анализира овакву употребу речи као и напомиње да се исказ (30б) може сматрати (из угла теорије релевантности) ироничним тек ако су остварена следећа три услова: (1) исказ је препознат као понављање туђих речи (што је директна веза са употребом речи као при цитирању [коментар А. J.]); (2) познато је коме те речи изворно припадају; (3) уочљиво је говорниково неодобравање тих речи. Ова три услова могу се применити на пример (31).

(30) А: Шта је Дана рекла? / а. Б: Доћи ће по мене. / б. Б: Као, доћи ће по мене. (Мишковић 2003: 180)

(31) Сећаш се оног звездочатца? ... Као - удариће комета на Курбан-бајрам, Земљину лопту, оде планета у прашину! Па кад је прошо Курбан-бајрам, а Земља осванула здрава и читава, ни комете, ни пропасти. (ЕК)

7. УВоЋЕњЕ ПРИмЕРА. Поред увођења управног и неуправног говора, реч као може увести и примере (пр. 32-33). Тада је заменљива фразом на пример одн. 
нпр. Веома често се ово значење лексеме као и експлицира употребом поменуте фразе уз као (пр. 34). У споју као на пример лексема као значењски се „празни”, што представља мост ка њеној катафоричкој употреби. Уместо лексеме као овде се може употребити као што.

(32) Тако [je] једног дана, крајем осамнаестог века, доспео - кромпир ... на трпезу француских владара ... да би се затим раширио по свету и добио ... најразличитије облике и називе, као [/ као што су]: брашњеник, карантен, алатум, холанђанин, слатки и, најзад, као круна квалитета, магнум бонум, бели.

(33) - Не видим зашто би требало на себе да преузимам кривицу. / - Да, али могао би да урадиш нешто у вези с тим. / - Као - шта? (ЕК)

(34) У Дечанској Хрисовуљи налази се чак 48 личних имена изведених од придевске основе „добар”, од којих су многа данас заборављена, као на пример: Добробуд, Доброгост, Доброхвал, Добретко итд. (ЕК)

8. КАТАФоРИЧкА УПотРЕБА. Деиктичка уПотреба лексеме као двоструко је мотивисана: синтаксичким положајем ове речи и њеним значењским „пражњењем”. Као се у тексту готово по правилу јавља испред садржаја који је под његовим опсегом, што је изнедрило катафоричку (а не анафоричку) употребу. С обзиром на то да реч као није пунозначна лексема, веома је тешко „ухватити” њен значењски садржај, па самим тим и констатовати њено значењско „пражњење”. Ипак, у примерима (35-36) реч као нема другу функцију до да упути на садржину дела текста који следи: заменљива је деиктичким прилогом за начин овако одн. изразом на следећи начин.

(35) Да ли то само моја усијана жеља чита ове редове као: долазим са новом женом, питала се разнежена сестра. (Варју 2008: 116)

(36) Мало кога могу да наведем да то прочита као: био је прохладан пролећни дан (Bapjy 2008: 116)

9. ИспуњивАч. Како би Попунио време које му је потребно да осмисли исказ, говорник користи значењски испражњене речи као испуњиваче, у које, пре свих, спадају поштапалице: овај, мис(л)им, ово, оно, како се зове и сл. Као које налазимо у пр. (37) могли бисмо придружити наведеном списку (у пр. 37 уз као употребљавају се и други испуњивачи, нпр. оно, мислим). Употреба лексема као у пр. (38) чини нам се ипак унеколико другачијом. Разматрајући примере из француског, италијанског, португалског и шпанског језика, Михач (2009: 84) наводи као могући окидач прагматикализације лексеме comme/come/como/como и контакт са другим језицима - првенствено са енглеским. Можда у томе лежи кључ необичне употребе лексеме као у пр. (38). Наиме, у енглеском се лексема like употребљава као маркер нове информације у исказу (Андерхил 1988, в. пр. 39), па би се могло претпоставити да се, аналошки према енглеском, у српском језику као почело употребљавати са сличном функцијом: да упути на дискурсну проминентност пропозиције која је под његовим опсегом (пр. 38). 
(37) „Па, мислим, оно, немам појма, јебига”, рекао ми је, бришући нос рукавом, „оно, мислим, као, јебига, шта има, као, сине, шта има, оно?” (EK)

(38) А: Јесте. И овај кум баш причао: „Е бре, умрећеш, стварно”. Зато што он дваес година само кока-колу пије, уопште воду не. / Б: Коิ и Којић, из зграде. Не зна га Петар. / В: Како га не зна! / А: Знам, знам! / В: Како га не зна! Као, ко њега не зна?! (Милосављевић 2014: 175)

(39) (One teacher telling another that some student reports are due sooner than expected) Second teacher: Like when? / First teacher: Like as soon as possible - today. (Андерхил 1988: 239)

10. УвоЋЕњЕ РЕченичнИХ конСтитуенатА. Други смер зНачењског гранања лексеме као подразумева њену граматикализацију. Разматрајући улогу контекста у процесу граматикализације, Б. Хајне (2002: 84-85) разликује два типа: bridging context и switch context. Први омогућава да се поред из ворног значења (source meaning) јави и ци љ но значење (target meaning), тј. представља својеврсни мост ка циљном значењу, при чему су обе интерпретације могуће (иако је циљно значење вероватније). Други пак искључује појаву изворног значења одн. посреди је својеврсно прекључи вање значења - циљно значење остаје једина могућа интерпретација. Управо ово нам може помоћи да разумемо континуум од поредбених до семикопулативних као-конструкција одн. као-конструкција у функцији актуелног квалификатива.

10.1. Допунски ПРедикАтив. Мост од поредбених до семикопулативних конструкција представљале би семикопулативне као-конструкција са глаголима изазивања утиска чији је допунски предикатив реализован именичком јединицом. У њима, како је реч о глаголима изазивања утиска, још увек имамо трагове поредбеног значења (исп. Варју 2008: 112), па се појам означен допунским предикативом може смататрати базом, а субјекатски појам метом. Тако у пр. (40) поравнавањем структура мете ('возач аудија') и базе ('грађанин Европе') искрсавају подударности везане за физички изглед - глагол изгледати у овом контексту означава визуелну перцепцију. У оваквим примерима допунски предикатив може се развити у реченицу, што карактерише већину правих поредбених конструкција (в. 1.2-1.5). Међутим, ако се глагол изгледати употреби у интелектуалном домену (да означи чулно засновану инференцијалну евиденцијалност), оваква реформулација је, у најмању руку, чудна (пр. 41). Исто важи и за глагол деловати (чија семантика је примарно инференцијалне природе) (пр. 42).

(40) Затим је возач аудија изашао напоље - био је то човек од тридесетак година у кожној јакни, добро обучен, изгледао је [онако] као [што изгледа] грађанин Европе. (ЕК)

(41) То опасно путовање данас ми изгледа ['онако] као ['што изгледа] гротескна епизода. (ЕК)

(42) Када би се на том месту појавио неко други, какав год да је био, нама застрашенима деловао је [?онако] као [?што нам делује] спасење. (ЕК) 
Семикопулативне као-конструкције са глаголима свесног приписивања својства појму (пр. 43-44) не отварају простор за поредбену интерпретацију одн. код њих долази до прекључивања значења. Премда, и даље се може говорити о поравнању - поравнању структура субјекатског/објекатског појма и појма означеног допунским предикативом. Посреди је вертикално поравнање: субјекатски/објекатски појам припада (у ширем смисли) надређеној категорији именованој допунским предикативом. Тако се у примеру (43) одређена група људи сврстава у категорију 'добрих људи' и 'вештих мајстора'. На овај начин се субјекатском/објекатском појму приписује дата квалификација. Допунски предикатив исказан као-конструкцијом могуће је заменити оним исказаним предлошко-падежном конструкцијом з $а$ + акуз. (као у пр. 43-44).

(43) Сви су они важили као добри људи и вешти мајстори [/ за добре људе и веште мајсторе]. Такав је и овај Аљо, само је помало особењак и на своју руку човек. (ЕК)

(44) Они пијанство постављају као једну књижевну потребу, алкохолизам сматрају као атрибут „богоданог” песника [/???за атрибут „богоданог” песника]. (ЕК)

10.2. АктУЕЛНи квАлИФикАТив. И ова уПотреба као-конструкције утемељена је на вертикалном поравнању структура појмова одн. на приписивању квалификације означене актуелним квалификативом. Међутим, сада вертикално поравнање наилази на својеврсно ограничење - временско. Тако, у примеру (45) 'човек' долази у тренутном својству 'везира', у примеру (46) 'црква' је имала тренутну намену 'дворска капела', у пример (47) 'Дух' силази у тренутном облику 'голуба'.

(45) Распитивали су се Травничани лево и десно, трошили и частили, само да би штогод сазнали о човеку који им долази као везир. (ЕК)

(46) Грађена је [Топчидерска црква] у исто време када и конак и служила је као дворска капела. (ЕК)

(47) Видје небо гдје се отвори, и Дух као голуб сиђе на њ. (РСАНУ)

У као-конструкцијама типа (48-49) актуелни квалификатив је по правилу реализован лексемама које саме по себи означавају одређени, ограничени временски период - типично старосну доб. Улога лексеме као јесте да уведе дати реченични конституент са временским значењем. Пошто је временско ограничење већ маркирано самом лексемом у функцији актуелног квалификатива, могуће је да је у овом случају дошло до значењског пражњења лексеме као одн. до њеног додатног функционализовања. Друга могућност је да лексема као и даље задржава значење временског ограничења, али да то није видљиво због значењског преклапања.

(48) Зар морам цео живот да једем само оно што сам јела као млада? (ЕК)

(49) Као клинац био је жешће растрзан између Команданта Марка, Милоша Обилића, Винетуа, Блека Стене, Принца Валијанта, Дон Кихота. (ЕК) 
Значењску мрежу лексеме као најилустартивније можемо резимирати скицирајући је. Наравно, скица служи само као помоћно средство за разумевање значења ове лексеме:

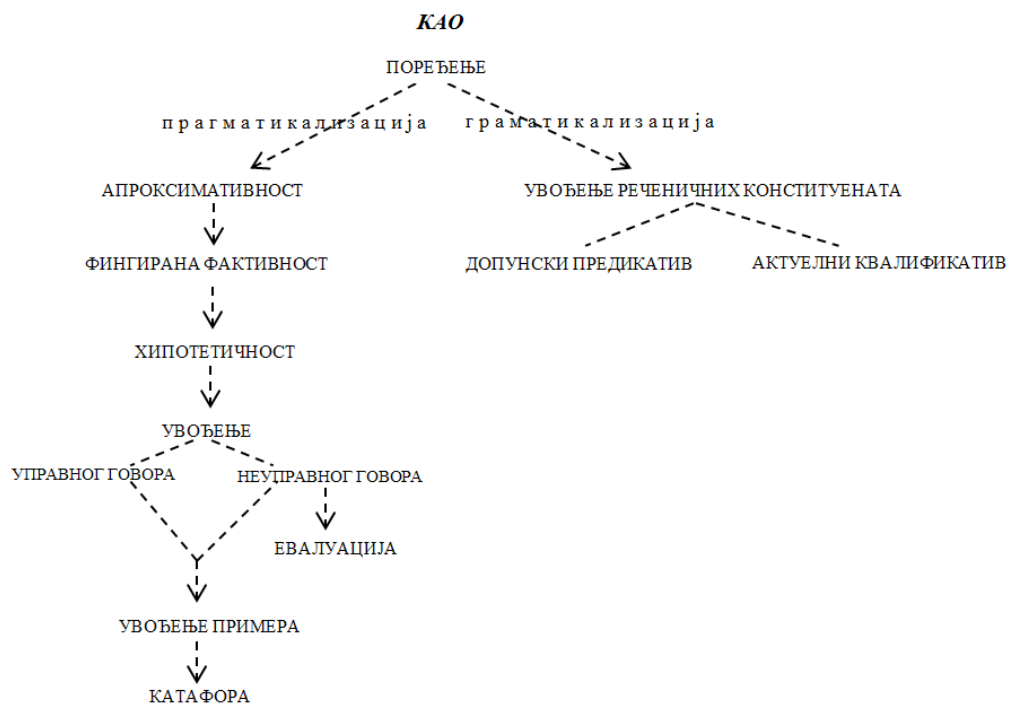

\section{III. У коју категорију спада реч као?}

1. ГРАМАТИЧКЕ КАТЕГОРИЈЕ И ТЕОРИЈА ПРОТОТИПА. Не СамО ЛеКСИЧКе НеГО И граматичке категорије имају прототипски организовану структуру: централни чланови дате категорије деле низ синтаксичких и семантичких својстава, док се они који имају мање заједничких особености налазе на периферији категорије (исп. Ланакер 1987; Тејлор ${ }^{3} 2003:$ 208-221, 2019). Како би ово илустровао, Теј-

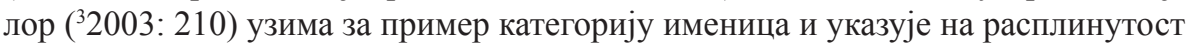
њених граница: наставник и сто су добри примери ове категорије, небо је мање добар пример, година, висина, срећа су маргинални представници категорије именица, док се пливање и долазак (будући да означавају активности или догађај) налазе на самој периферији. Ако имамо у виду широк опсег употреба лексеме као, занимљиво би било размотрити у које врсте речи она спада односно, казано когнитивнолингвистичким речником, којим категоријама се може прикључити, те какво би било њено чланство.

1.2. ВЕзник? Везници се начелно деле на напоредне и зависне: напоредни везници означавају напоредни однос између две или више функционалних јединица (то могу бити речи, синтагме, реченице), а зависни везници уводе зависну реченицу као конституент више реченице (Поповић Љуб. ${ }^{11} 2008:$ 307, 354-357). 
Оваква дефиниција везника намеће закључак да поредбено као није везник. Оно не исказује напоредан однос - стога, није напоредни везник. Исказује зависан однос, али не уводи зависну реченицу, него реч као зависан члан синтагме - па према граматичкој литератури, не може бити ни зависан везник. Из овога искрсава следеће питање: зашто се зависни везници односе само на увођење зависних реченица у вишу? зашто не би уводили и друге синтаксичке јединице - нпр. речи као зависне чланове синтагми? Увођење зависне реченице у вишу била би прототипична функција зависних везника; међутим, то не значи да из њиховог опсега треба искључити све што је мање типично. Поредбено као се стога може сматрати зависним везником, иако је, чини нам се, уз везник него, једини таквог типа.

Док у поредбеним конструкцијама лексема као уводи реч као зависан члан синтагме (као синтагматски конституент - нпр. Смеје се нежно као дете), у семикопулативним конструкцијама и конструкцијама у функцији актуелног квалификатива, она уводи реч као реченични конституент (нпр. Као дете волела сам да возим тротинет). Овде више не можемо говорити о маркирању односа зависности везником; везник се још више функционализује и његова функција постаје увођење реченичног конституента. Дакле, поделу везника на напоредне и зависне треба „расплинути” тако да обухвати и друге случајеве - премда малобројне, али значајне.

1.3. Речца? Свим граматикама је у дефинисању речци заједничко то што истичу да речце означавају лични став говорника према пропозицији. Ово пре свега важи за модалне речце, те можемо закључити да су оне, уз конекторе, прототипични представници ове врсте речи са врло расплинутим и нејасним границама, са више центара (модалне речце, текстуални конектори и сл.). Када је реч као епистемички маркер или када имплицира говорников негативан став према пропозицији, могла би се сврстати у категорију речци, и то као њен прототипичан представник. Међутим, постоје случајеви када се ова реч налази на самој периферији категорије речци, те улази у домен категорије прилога, заузимајући и у овој категорији периферно место. То би илустровала употреба описана у т. 2: речју као модификује се значење предиката. Када се лексема као катафорички употреби, она постаје деиктичка реч и приближава се заменичким прилозима за начин.

Да су поредбено као и као које није део пропозиције различитог типа - једно има семантичку, друго прагматичку вредност - добро илуструје следећи пример: Он је юој као као брат, а у ствари је заљубљена у њега (разг.) = Он је њој „као брат”, а у ствари је заљубљена у њега. Прво као имплицира говорникову дистанцу према пропозиционом садржају, док је друго као део пропозиције и успоставља поредбени однос. 


\section{ИЗВОРИ}

ЕК: Корпус савременог српског језика [Претрага корпуса са изворима, 2013]. http://www.korpus.matf.bg.ac.rs.

PMC: Речник српскохрватскога књижевног језика, I-VI, Нови Сад - Загреб: Матица српска - Матица хрватска, 1967-1976.

РСАНУ: Речник српскохрватског књижевног и народног језика, I-XX, Београд: САНУ, $1959-$.

PCJ: Речник српскога језика, Нови Сад: Матица српска, 2007.

Савић/Половина 1989: S. Savić i V. Polovina, Razgovorni srpskohrvatski je$z i k$, Novi Sad: Institut za južnoslovenske jezike Filozofskog fakulteta.

Милосављевић 2014: Б. Милосављевић, Оговарање као говорни жанр свакодневне комуникације, Београд: Институт за српски језик САНУ.

\section{ЛИТЕРАТУРА}

Андерхил 1988: R. Underhill, Like is, like, focus, American Speech, 63, 3, Durham, 234-246.

Баудли/Гентнер 2005: B. Bowdle and D. Gentner, The career of metaphor, Psychological review, 112/1, 193-216.

Bapjy 2008: А. Варју, О једном типу поредбених конструкција, Прилози проучавану језика, 34, Нови Сад, 109-123.

Вишер 2006: I. Wischer, Grammaticalization, in: K. Brown (ed.), Encyclopedia of Language and Linguistics, Amsterdam: Elsevier, 129-135.

Илић 1981: В. Илић, Поредбена конструкција са везником као и композитумом као и, Научни састанак слависта у Вукове дане, 7/1, Београд, 343-364.

Јовановић 2018: А. Јовановић, О неким необичним употребама глагола доћи (Он ми дође брат од стрииа / То му дође субота), Језик данас, 11, Нови Сад, 30-36.

Кликовац 2006: D. Klikovac, Semantika predloga: studija iz kognitivne lingvistike, Beograd: Filološki fakultet.

Кликовац 2017: Д. Кликовац, О употреби заменичких прилога за време онда и тад(а), у: Р. Драгићевић (ур.), Путевима речи - Зборник у част Даринки Гортан Премк, Београд: Филолошки факултет, 495-516.

Кликовац 2018: Д. Кликовац, О систему заменичких прилога за место у српском језику: прилог тамо, у: Р. Драгићевић и В. Брборић (ур.), Српска славистика: колективна монографија / Том 1, Језик, Београд, 125-140.

Ланакер 1987: R. Langacker, Nouns and verbs, Language, 63/1, 53-94. 
ЛејкофЏонсон 1980: G. Lakoff and M. Johnson, Metaphors We Live By, Chicago - London: University of Chicago Press.

Лејкоф 2014: Џ. Лејкоф, Когнитивни модели и теорија прототипа (прев. М. Беланов), у: К. Расулић и Д. Кликовац (ур.), Језик и сазнање: хрестоматија из когнитивне лингвистике, Београд: Филолошки факултет, 105-150.

Маретић ${ }^{3}$ 1963: T. Maretić, Gramatika hrvatskoga ili srpskoga književnog jezi$k a$, Zagreb: Matica hrvatska.

Миљковић 2016: В. Миљковић, Поредбене конструкције са оператором као у савременом српском језику, у: М. Ковачевић и Ј. Петковић (ур.), Савремена проучавања језика и књижевности: зборник радова са VII научног скупа младих филолога Србије, Крагујевац: ФИЛУМ, 199-212.

Михач 2009: W. Mihatsch, The approximators French comme, Italian come, Portuguese como and Spanish como from a grammaticalization perspective, in: C. Rossari, C. Ricci and A. Spiridon (eds.), Grammaticalization and Pragmatics. Facts, Approaches, Theoretical Issues, BRILL, 65-91.

Мишковић 2003: M. Mišković, Relevance-theoretic semantics and the Serbian pragmatic marker kao, u: D. Klikovac i K. Rasulić (ur.), Jezik, društvo, saznanje: Profesoru Ranku Bugarskom od njegovih studenata, Beograd: Filološki fakultet, 165-184.

Мишковић Луковић 2010: M. Mišković Luković, Markers of conceptual adjustment: Serbian baš and kao, in: M. Dedaić and M. Mišković Luković (eds.), South Slavic Discourse Particles, Amsterdam: John Benjamins Publishing, 65-89.

Московљевић 1958: М. Московљевић, У коју категорију спада реч „као”?, Наш језик, IX, Београд, 243-259.

Новаковић ${ }^{2}$ 1902: С. Новаковић, Српска граматика, Београд: Државна штампарија.

Норд 2009: М. Norde, Degrammaticalization, Oxford: Oxford University Press.

Поповић Љуб. 112008: Љуб. Поповић, Синтакса, у [књизи]: Ж. Станојчић и Љ. Поповић, Граматика српскога језика за I, II, III и IV разред средње школе, Београд: Завод за уџбенике.

Поповић Људ. 2012: Људ. Поповић, Контрастивна граматика српског и украјинског језика: таксис и евиденцијалност, Београд: САНУ.

Ромеин/Ланг 1991: S. Romaine and D. Lange, The use of like as a marker of reported speech and thought. A case of grammaticalization in progress, American speech, 66, 3, Durham, 227-279.

Стевановић 51986: М. Стевановић, Савремени српскохрватски језик I, Београд: Научна књига.

Тејлор ${ }^{32003:}$ J. Taylor, Linguistic Categorization, New York: Oxford University Press.

Тејлор 2019: J. Taylor, Prototype effects in grammar, in: E. Dąbrowska and D. Divjak (eds.), Cognitive Linguistics - Key Topics, Berlin: Walter de Gruyter, 127-146.

Хајне 2002: B. Heine, On the role of context in grammaticalization, in: I. Wischer and G. Diewald (eds.), New Reflections on Grammaticalization, Amsterdam-Philadelphia: John Benjamins Publishing Company, 49, 83-102. 
Aleksandra S. Jovanović

\section{ON THE LEXEME KAO (ENGL. LIKE) FROM THE ANGLE OF THE PROTOTYPE THEORY}

Summary

This paper aims at analyzing the semantic network of the lexeme kao (Engl. like) as well as discussing its membership in the categories of conjunctions, adverbs, and particles from the cognitive linguistics perspective, with the prototype theory as a more specific framework. It is argued that the use of the word kao in the comparative construction is its prototypical use, to which all others are related in the network structure. The network structure is based on two main processes: pragmaticalization and grammaticalization. The first one is responsible for pragmatic uses of this lexeme, e.g. the cataphoric use. The second process is liable for its grammatical uses (e.g. in pseudocopulative constructions). After outlining the semantic network of the lexeme kao, we provide one possible answer to the question in which word classes this lexeme should be placed. Based on the category-as-prototype approach, the word classes are also considered as categories with fuzzy boundaries.

Key words: Serbian language, lexeme kao, comparative construction, pragmaticalization, grammaticalization, word classes, prototype theory, Cognitive Linguistics. 